Л. Н. Ганич // Зб. наук. праць УкрДАЗТ. 2013. - Вип. 135. - С. 131 - 135.

6. Європейська комісія [Електронний ресурс]. - Режим доступу: http://ec.europa.eu/transport/publications/stati stics/. - Назва з титул. екрану.

7. Залізниці України відремонтували 21 переїзд та на 46 уклали переїзний залізобетонний настил [Електронний ресурс] - Режим доступу: http://www.uz.gov.ua/press_center/up_to_dat e_topic/408644/. Назва 3 титул. екрану.

8. Міщенко M.I. Перспективні напрямки розвитку транспортної системи
3 урахуванням стратегічних пріоритетів національної економіки [Текст] / M.I. Міщенко, О.М. Кириленко // Збірник наукових праць ДНУЗТ імені В. Лазаряна «Проблеми економіки транспорту». 2016. - вип. 11. - с. 74-80.

9. Пінчук С.С. Оцінка ефективності функціонування підприємств залізничного транспорту на сучасному етапі / C. C. Пінчук // Науковий журнал «Економічний форум». - № 1. - Луцьк: ЛНТУ, 2016. - С. 203-208.

\title{
АКТУАЛЬНІ ПИТАННЯ ТАРИФНОГО РЕГУЛЮВАННЯ ТЯГИ ТА ВАРТОСТІ ЖИТТЕВОГО ЦИКЛУ ЛОКОМОТИВУ
}

\author{
Галушко О.І., директор консалтингової компанії (ТОВ «АРЛЕН»), \\ ст. викладач (ДВНЗ ПДАБА)
}

В статті розглядаються підходи та методи формування тарифів на вантажні залізничні перевезення, проблеми оновлення тягового рухомого складу ПАТ «Укрзалізниия». Аналізується структура тарифів та доиільність їх підвищення. Досліджуються тарифні складові тяги, структура життєвого ииклу локомотиву та вплив на нього модернізації. Розглядаються сучасні технологї модернізації. Запропоновано використання механізмів конщесії та державно-приватного партнерства на різних стадіях життєвого ичиклу.

Ключові слова: тариф, вантажні перевезення, тяга, метод Рамсея, локомотив, жнттевий цикл, поточні і капітальні витрати, модернізація.

\section{АКТУАЛЬНЫЕ ВОПРОСЫ ТАРИФНОГО РЕГУЛИРОВАНИЯ ТЯГИ И СТОИМОСТИ ЖИЗНЕННОГО ЦИКЛА ЛОКОМОТИВА}

\author{
Галушко Е.И., директор консалтинговой компании (ООО «АРЛЕН»), \\ ст. преподаватель (ГВУЗ ПГАСА)
}

В статье рассматриваются подходы и методы формирования тарифов на грузовые железнодорожные перевозки, проблемь обновления тягового подвижного состава ПАО «Укрзализница». Анализируется структура тарифов и целесообразность их повышения. Исследуются тарифные составляющие тяги, структура жизненного цикла локомотива и влияние на него модернизаџии. Рассматриваются современные технологии модернизачии. Предложено использование механизмов конщессии и 
государственно-частного партнерства на различных стадиях жизненного иуикла.

Ключевые слова: тариф, грузовые перевозки, тяга, метод Рамсея, локомотив, жсизненный цикл, текущие и капитальные расходы, модернизация.

\section{ACTUAL QUESTIONS THE TARIFF REGULATION OF LOCOMOTIVES TRACTION AND THE COST OF LOCOMOTIVES LIFE CYCLE}

\section{Galushko O.I., CEO of consulting company (ARLEN LLC), senior lecturer (SHEI PSACEA)}

The article deals with approaches and methods of formation the tariffs for railway freight and problems of renovation the traction rolling stock of JSC "Ukrzaliznytsia". The structure of tariffs and advisability of their increasing are analyzed. The tariff components of traction, the structure of the locomotive's life cycle and the impact of modernization are investigated. Modern technologies of modernization are considered. Using of concession and public-private partnerships methods at different stages of the life cycle is offered.

Keywords: tariff, freight, traction, Ramsey method, locomotive, life cycle, current expenses and investments, modernization.

\section{Постановка}

Характерною особливістю політики ціноутворення залізничної монополії є іiі тарифне регулювання. В сучасних умовах в якості основного методу застосовується тарифно-фіскальне регулювання, яке повинно забезпечувати баланс інтересів споживачів, експлуатантів, інфраструктурної монополії (УЗ) i держави. Необхідність тарифнофіскального регулювання обумовлена стратегічним, економічним і соціальним значенням об'єктів інфраструктури залізничного транспорту.

Практика тарифоутворення на залізничні перевезення, що склалась в Україні, базується на адміністративному регулюванні тарифу, корупційних схемах та політичному впливі ставлеників фінансово-промислових груп в міністерствах. Отже, основу існуючого тарифоутворення складають витрати на функціонування Укрзалізниці та фінансові інтереси осіб, що приймають рішення. Для ефективного реформування і розвитку галузі, підвищення економічної ефективності, безпеки та якості залізничних перевезень, Укрзалізниця має перейти до утворення тарифів на принципах економічної обгрунтованості та конкурентного підходу.

На сьогоднішній день питання регулювання тарифів на залізничні перевезення є стратегічно важливим, адже 3 одного боку, УЗ потрібні фінансові ресурси для оновлення парку вагонів, локомотивів та залізничної інфраструктури, розвитку нових напрямків вантажо- та пасажиропотоків. 3 іншого боку, подальше підвищення тарифів негативно позначиться на конкурентоспроможності вітчизняних товаровиробників і самої Укзалізниці i може призвести до скорочення обсягів перевезень та часткового відтоку вантажів та пасажирів на альтернативні види транспорту.

Аналіз останніх досліджень i публікацій. Теоретичні та методологічні основи ціноутворення та тарифного регулювання на залізничному транспорті розглядаються в роботах таких українських вчених, як М.М. Колесникова [1], Ю.С. Бараш [2], І.П. Корженевич, В.В. Чорний [3], В.Л. Дикань [4], О.М. Гненний, Н.В. Чебанова [5], М.В. 
Макаренко, H.I. Богомолова, Х.Г. Кравченко, О.Г. Кірдіна [6] і інших. Актуальні проблеми формування оптимального парку локомотивів в умовах кризи розглянуті нами в роботі [7].

За останній час вантажні тарифи Укрзалізниці було суттєво збільшено. В 2013 р. тарифи зросли на 11\%, 3 липня 2014 р. - на 12,5\%, з лютого 2015 р. - на $30 \%$, з кінця липня 2015 р. - ще на 12,5\%. У 2016 р. планувалося 2 етапи підвищення вантажних тарифів, але через протести галузевих асоціацій вантажовідправників це рішення спочатку було відкладено, в результаті тарифи зросли 3 кінця квітня 2016 р. на $15 \%[8,9]$.

У лютому 2017 p. Державна регуляторна служба відхилила підвищення тарифів на залізничні вантажоперевезення - тим не менш, Голова правління УЗ Войцех Бальчун сподівається на підвищення тарифів на вантажні перевезення ще на 25\% і на пасажирські перевезення на $35 \%$. Але за підрахунками У3, пасажирські перевезення навіть за підвищення тарифів вимагатимуть перехресного субсидіювання, тобто залишаться тягарем на тарифі вантажних перевезень [10].

За даними одних джерел, 32008 року індекс росту цін щорічно перевищує індекс росту тарифів на залізничні перевезення. Також зазначається, що в Україні вартість залізничних вантажоперевезень в рази нижче, ніж в інших країнах $Є С$ та СНД $[10,11]$. Інші джерела повідомляють, що в Україні спостерігається зниження темпів зростання промислового виробництва, а вартість залізничних вантажоперевезень $\epsilon$ необгрунтованою i вже надвисокою для українських товаровиробників, що призводить до відтоку вантажів на інші види транспорту (зокрема, доля автотранспорту у перевезенні зернових в морські порти України зросла з 25\% у 2012 р. до $32 \%$ у 2015 р.) $[9,11]$.

Укрзалізниця підтверджує, що вантажні перевезення $є$ рентабельними (при цьому рівень рентабельності не розголошується), а вимоги підняти тарифи пояснюе необхідністю подальшого перехресного субсидіювання пасажирських перевезень та потребою в інвестиційних ресурсах для оновлення активів.

Отже ситуація, що склалася зі зростанням тарифів У3 на вантажоперевезення, викликає питання про економічну обгрунтованість i доцільність таких рішень та вимагає подальшого дослідження i розробки ефективних механізмів тарифного регулювання.

Виділення невирішених частин загальної проблеми. Тарифна зарегульованість $\epsilon$ характерною для залізничного транспорту України вже тривалий час. Перш за все, це стосується жорсткого державного регулювання тарифів в частині інфраструктурної та локомотивної складової [3]. Ринкові зміни вимагають розробки нових ефективних механізмів тарифоутворення, адже вони мають забезпечити Укрзалізницю ресурсами для оновлення активів, перш за все, локомотивів, парк яких $\epsilon$ майже повністю зношеним [7].

Рішення щодо зростання тарифів та спрямування коштів на оновлення активів мають бути виваженими та економічно обгрунтованими. Наприклад, закупівля нового рухомого складу за рахунок відтермінування поточних ремонтів та обслуговування може дати короткостроковий ефект покращення, але в майбутньому призведе до додаткових витрат на оновлення активів, адже їх неналежне утримання призводить до пришвидшеного зносу [12].

Брак фінансових ресурсів не дозволяє УЗ оновлювати парк локомотивів та призводить до «технологічного канібалізму» та погіршення якості i безпеки залізничних перевезень. Розробка ефективних механізмів ціноутворення та тарифного регулювання тяги $\epsilon$ найважливішими факторами, що

Вісник економіки транспорту і промисловості № 58, 2017 
впливають на конкурентоспроможність залізничних перевезень і можливості експлуатанта здійснювати модернізацію тягового рухомого складу в умовах кризи.

Метою статті $\epsilon$ дослідження особливостей тарифного регулювання i тарифних складових тяги, впливу модернізації на зміну вартості життєвого циклу локомотива.

Виклад основного матеріалу дослідження. Під тарифом розуміють певну ставку (норму сплати) або сукупність ставок. Транспортний тариф це ціна за переміщення матеріального об'єкта в просторі. Система транспортних тарифів складається 3: плати за перевезення вантажів; зборів за додаткові операції, пов'язані 3 перевезенням вантажів; правил обчислення плат і зборів.

При розгляді принципів утворення тарифів на залізничному транспорті слід зауважити наступне.

1. Вантажні перевезення збільшують вартість продукції для кінцевого споживача, отже виникає конфлікт інтересів УЗ, що намагається збільшити тарифи та отримати додаткові кошти, та виробників i споживачів продукції, які бажають зберегти цінову конкурентоспроможність та отримувати якісні транспортні послуги за мінімальну ціну.

2. Пасажирські перевезення надають соціально важливу послугу. При цьому виникає конфлікт інтересів УЗ, що не задовільнена збитковістю пасажирських перевезень, та громадян, які теж бажають отримувати якісні транспортні послуги за мінімальну ціну.

Це обумовлює необхідність державного регулювання тарифів на продукцію (послуги) природних монополій, що здійснюється відповідно до ст. 8 Закону України "Про природні монополіі”. Ефективне державне регулювання дозволяє розв'язати конфлікт інтересів зацікавлених сторін (стейкхолдерів) - держави, Укрзалізниці, вантажовідправників та споживачів їх продукції, пасажирів. Але для цього державне регулювання має базуватись на конкурентному підході, тобто забезпеченні конкурентної позиції природної монополії.

В світовій практиці виділяють два підходи до ціноутворення на залізничні перевезення - конкурентний, що базується на конкурентній позиції залізниці, та витратний, що базується на витратах на функціонування залізниці (рис. 1). В більшості розвинених країн використовуються змішані системи ціноутворення, але можна виділити 3 основні методи [8,9]): «середні витрати + +», «маржинальні витрати +» та метод Рамсея, що використовується переважно в умовах залізничної монополії (в країнах СНД, Великобританії, США).

Верхня межа тарифу визначається платоспроможністю споживачів, нижня межа - витратами залізничної монополії. Оптимальна ціна знаходиться в зазначеному інтервалі, при виході тарифу за його верхню межу неминучим стає субсидування споживачів, а при виході за нижню межу - інфраструктурної монополії.

За методом Рамсея тариф на вантажні перевезення залежить не тільки від ваги та відстані, а й від виду вантажу, адже залізниця встановлює націнку до своїх змінних витрат зворотно пропорційно еластичності попиту клієнтів. Тобто більш висока націнка встановлюється для клієнтів 3 низькою еластичністю попиту, які не мають змоги переключитися на альтернативні види транспорту (вугледобувні, залізорудні та інші сировинні компаніі), а низька націнка - для клієнтів 3 високою еластичністю попиту (контейнерні оператори, що перевозять готову продукцію). Отже, за методом Рамсея залізниця встановлює більш високі тарифи для виробників продукції 3 низькою доданою вартістю (вугілля, залізна руда та інша сировина), та нижчі тарифи для виробників з високою доданою вартістю (готова продукція, що

Вісник економіки транспорту і промисловості № 58, 2017 
транспортується в контейнерах). В національної економіки держава має сучасних умовах метод Рамсея доцільно стимулювати саме виробництво продукції використовувати 3 певними обмеженнями, 3 високою доданою вартістю.

адже для ефективного розвитку

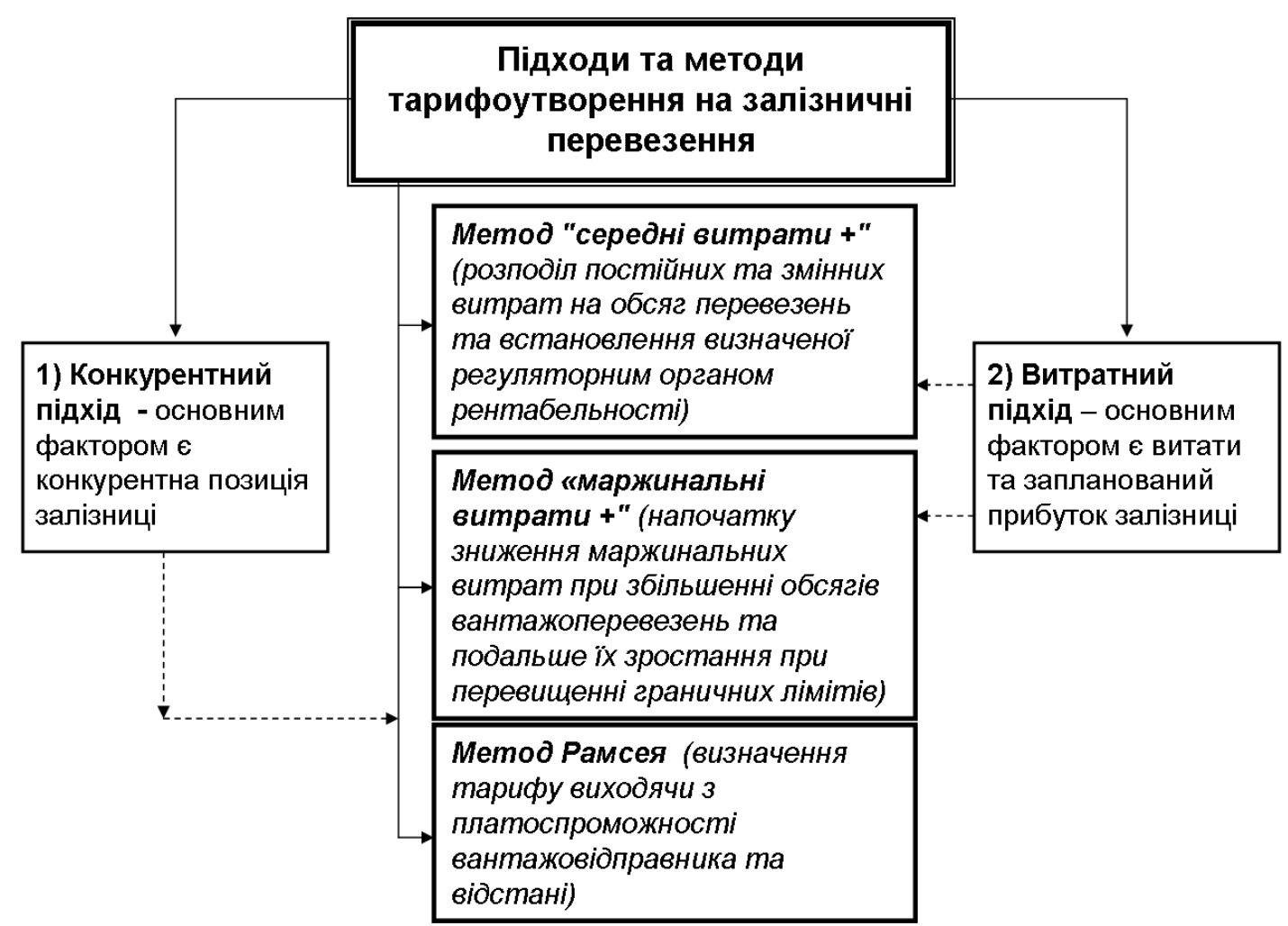

Рис. 1. Підходи та моделі утворення тарифів на залізничні перевезення (складено автором за [8, 9])

Наприклад, в Україні різниця у тарифі на різні вантажі досягає 2,8 разів. Біля 50\% внутрішніх вантажоперевезень УЗ складають вугілля, цемент та залізна руда, тобто продукція з низькою доданою вартістю, собівартість якої більш чутлива до транспортної складової. Попит виробників цієї продукції на транспортні послуги УЗ є нееластичним, отже, самі ці галузеві асоціації постійно висловлюють невдоволення підвищенням тарифів.

При розрахунку залізничних тарифів виділяють 3 складових - вагонну, інфраструктурну (в т.ч. вокзальну) i локомотивну (рис. 2).

Частка локомотивної складової УЗ росла в зв'язку з катастрофічним зносом парку i досягає 60\%. Змінити таке критичне співвідношення складових тяги дозволяє модернізація, яка забезпечує скорочення експлуатаційних витрат та витрат на поточні і позапланові ремонти. Для порівняння - в США тариф вантажних перевезень включає п'ять елементів: вагонну, локомотивну, інфраструктурну, а також адміністративну і експлуатаційну. Локомотивна складова тарифу займає близько $20 \%$.

Для планування i оцінки витрат i фінансових результатів експлуатації локомотивів слід аналізувати не тільки тарифні складові тяги, а й життєвий цикл локомотива, тому що співвідношення тарифних складових залежить від стадії життєвого циклу. Життєвий цикл локомотива (рис. 3) являє собою період від визначення функціональних потреб і 
початку розробки технічних рішень до закінчення терміну служби локомотива.

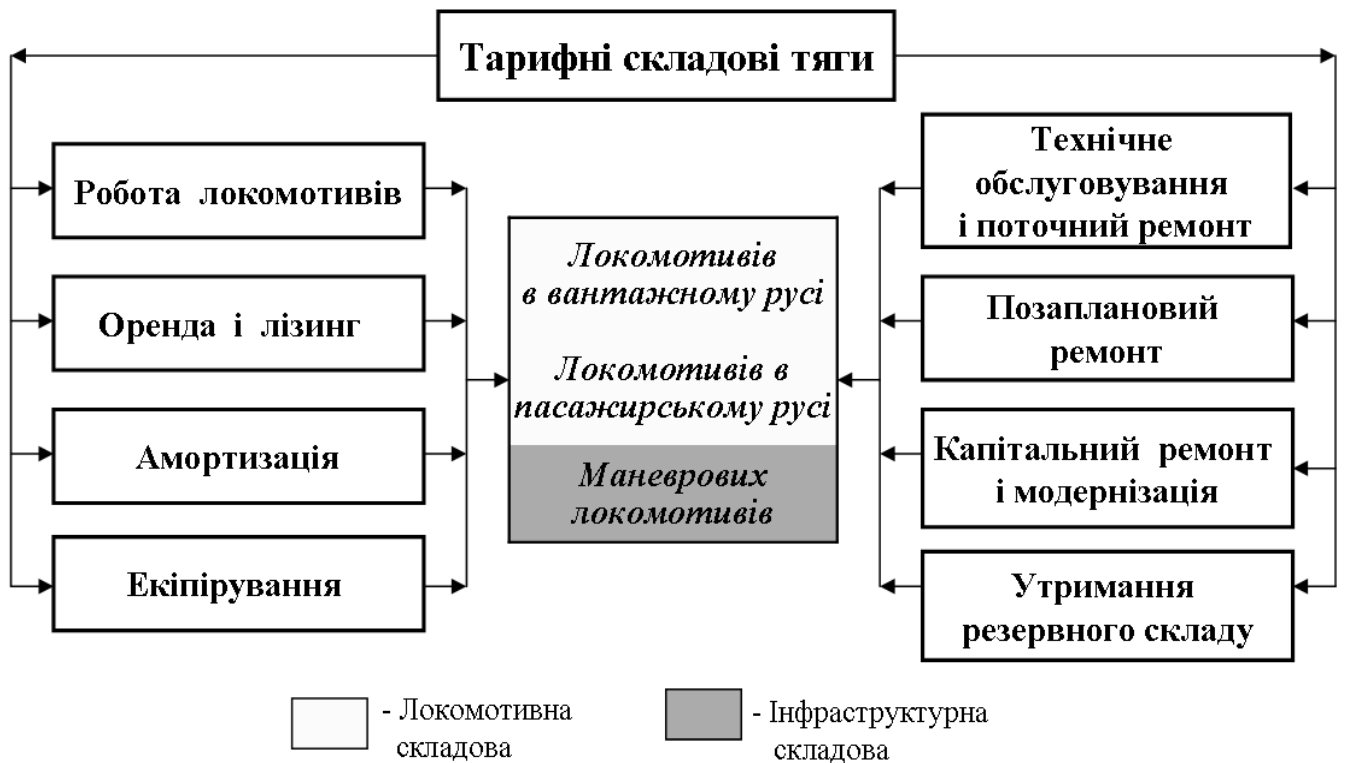

Рис. 2. Тарифні складові тяги (складено автором за $[2,3])$

стадії життєвого циклу (1-5)

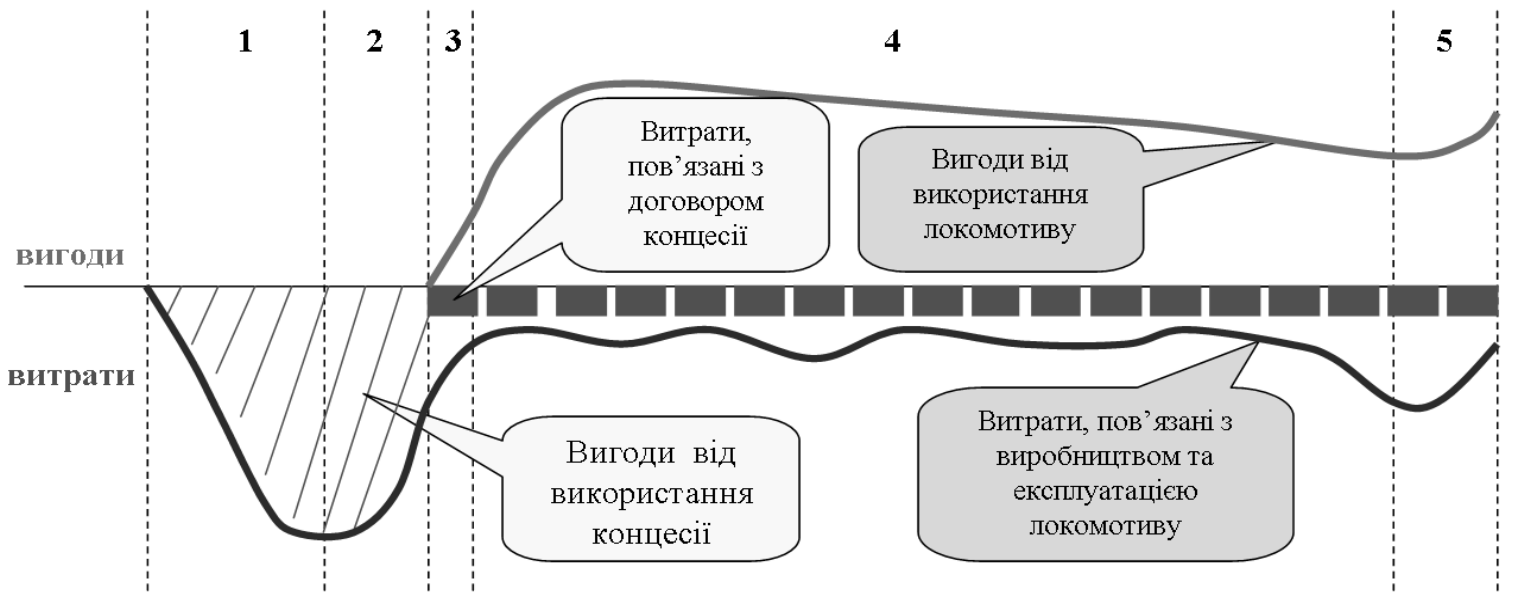

1 - Розробка технічних рімень, НДДКР

2 - Виготовлення локомотиву;

3 - Введення локомотива в експлуатауію (з навчанням персоналу, дооснащенням ремонтної бази і m.n).

4 - Експлуатація і технічне обслуговування локомотиву;

5 - Модернізауія або вилучення (утилізачія) локомотиву

Рис. 3. Стадії життєвого циику локомотива (складено автором)

На стадіях 1-2 здійснюється моделей i умов їх використання, проектування і виготовлення локомотива, прогнозування попиту, НДДКР i в т.ч. дослідження ринку, визначення проектування, виготовлення i функціональних вимог до перспективних випробування, запуск в серійне 
виробництво. Стадії 3-5 - це власне час експлуатації локомотива від початку до його утилізації [13].

Проблема оновлення парку локомотивів може бути вирішена як за рахунок придбання нової техніки, так і за рахунок модернізації тягового рухомого складу, що експлуатується. Вартість життєвого циклу є критерієм оцінки нових i модернізованих локомотивів в довгостроковій перспективі. Протягом життєвого циклу локомотива його власник несе капітальні витрати (інвестиції) i поточні витрати (експлуатаційні витрати) за термін його корисного використання.

При продажу локомотива витрати постачальника містяться в ціні i компенсуються покупцем у вигляді капітальних витрат на придбання локомотива. Величина капітальних витрат впливає на термін окупності інвестицій на поповнення тягового рухомого складу. У разі оренди локомотива або його використання за договором концесії експлуатант звільняється від капітальних витрат. Експлуатаційні (поточні) витрати включають витрати на паливо, матеріали, оплату праці локомотивних бригад, екіпірування і технічне обслуговування, а також ремонт локомотивів. Поточні витрати впливають на результати фінансово-господарської діяльності експлуатанта, адже співвідношення доходів i витрат має забезпечити запланований прибуток.

Що стосується модернізації активів УЗ - вона має здійснюватись за рахунок прибутку монополії. Вартість модернізації збільшить вартість активів компанії, а отже і амортизаційні відрахування, що включені в собівартість та ціну транспортних послуг УЗ для споживача. Таким чином, вартість модернізації через амортизаційні відрахування закладається в тариф і намагання УЗ збільшувати тарифи на рентабельні вантажні перевезення не $\epsilon$ обгрунтованими особливо в умовах, коли монополія не виконує планів інвестицій (за 10 місяців 2016 p. інвестиції в оновлення активів склали 3,8 млрд. грн замість запланованих 11,2 млрд. грн) та замість того збільшує операційні витрати (за 10 місяців 2016 р. інші операційні витрати зросли на 31\%) [11].

Модернізація дозволяє збільшити час міжремонтного пробігу, суттєво скоротити витрати на ТО і ТР, а значить змінити структуру вартості життєвого циклу локомотива (рис. 4).

За даними ПАТ «Полтавський тепловозоремонтний завод» (ПАТ «ПТРЗ»), модернізація на третину зменшує поточні витрати експлуатанта (а отже, зменшується собівартість робіт, що виконуються на локомотиві), але на третину збільшуе капітальні витрати (інвестиціï).

Hе всі експлуатанти можуть дозволити собі капітальні інвестиції для заміни старих локомотивів на нові. Але у разі отримання модернізованого локомотиву в оренду або концесію експлуатант звільняється від капітальних витрат. При цьому поточні витрати будуть дещо збільшені, але експлуатант отримає економію на технічному обслуговуванні та витратах на енергоресурси.

Розвиток технологій модернізації 3 кожним роком дозволяє використовувати все більш надійні агрегати. При цьому модернізована техніка дешевше i не поступається новій за надійністю i ефективністю експлуатації. У тяговому рухомому складі, що модернізується сьогодні, слід максимально враховувати кращий накопичений світовий досвід, та розглядати не окремі конструктивні рішення, а сучасні комплексні рішення та сукупний результат їх імплементації.

Застосування сучасних технологій модернізації вимагає нових підходів до технічного обслуговування i ремонту, удосконалення системи матеріальнотехнічного забезпечення запасними частинами, підвищення кваліфікації персоналу підприємства, що виконує модернізацію, та експлуатанта. Отже, модернізація є технічним переозброєнням,

Вісник економіки транспорту і промисловості № 58, 2017 
що вимагає скоординованих зусиль всіх постачальників,

виконавців, учасників процесу: замовників, експлуатантів.

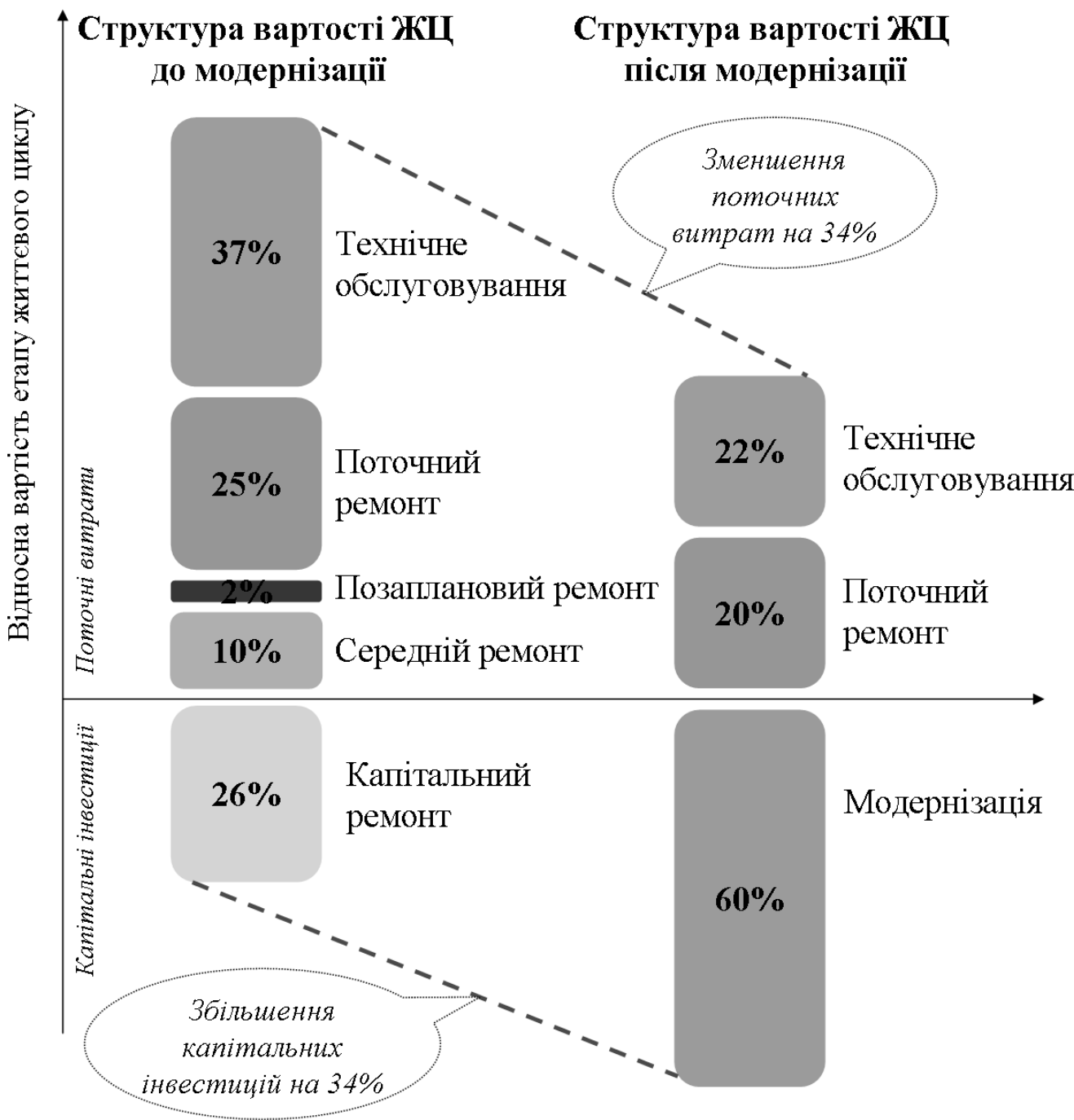

Рис. 4. Зміна структури вартості життевого ичиклу локомотиву при модернізації (складено автором за інформачією ПАТ «ПТРЗ»)

Розглянемо сучасні технології модернізації локомотивів. Найважливішим резервом поліпшення енергетичних характеристик тепловозів в процесі модернізації $\epsilon$ підвищення ККД енергосилового устаткування за рахунок використання сучасних дизельгенераторних установок, усунення негативів холостого ходу дизеля, застосування накопичувачів електричної енергії, що дозволяють на тепловозах фактично реалізувати рекуперативне гальмування 3 подальшим корисним використанням накопичуваної при гальмуванні електроенергії.

Наприклад, при модернізації ТЕ10М дизель-генератор i його системи замінюються на уніфікований силовий модуль SuperSkid ${ }^{\mathrm{TM}}$ виробництва General Electric, який складається 3 дизеля 7FDL12, що представляє собою чотиритактний двигун 3 турбонаддувом i проміжним охолодженням наддувочного повітря. Даний двигун оснащується системою електронного управління уприскуванням палива (EFI), яка обладнана всіма 
необхідними датчиками та інтерфейсом для системи управління BrightStar ${ }^{\mathrm{TM}}$ Sirius $^{\mathrm{TM}}$. Також $є$ можливим варіант модернізації TE10M із застосуванням дизеля 16ЧН26/26 i генератора ГС-501 виробництва ДП «Електроважмаш» на базі дизельгенератора 1А-9ДГ ВАТ «Коломенський завод».

Можуть розглядатись і альтернативні варіанти модернізації тепловозів наприклад, варіант переведення тепловозу на скраплений газ. При цьому газотепловоз буде складатися 3 трьох секцій: дві дизельні і одна кріогенна, що міститиме ємності зі скрапленим природним газом.

Маневрові тепловози ЧМЕ3 модернізуються 3 використанням блочномодульної конструкції з дизель генератором CAT 3508/631 потужністю 970 кВт, або САТ 3512/631 потужністю 1455 кВт. Також опрацьовано варіант модернізації із застосуванням дизеля MTU 8V 4000 R43 потужністю 970 кВт і генератора виробництва заводу ДП «Електроважмаш».

Модернізація ЧМЕ3 можлива iз застосуванням двохдизельної силової установки. Таке рішення підвищуе надійність тепловоза, продовжує термін служби кожного дизель-генераторного агрегату, розширює можливості їх регулювання. Досвід модернізації тепловозів ПАТ «ПТРЗ» показує, що для тепловоза ЧМЕЗП досягається: $30 \%$ економія палива, 80\% економія олій і на 40\% збільшується міжремонтний пробіг. Для тепловоза 2ТЕ10М економія палива становить $20 \%$, економія олій $75 \%$, збільшення міжремонтного пробігу $25 \%$.

В умовах здороження електроенергії важливим фактором модернізації електровозів є зниження енергоспоживання. Модернізація електровоза постійного струму ВЛ11М, що виконується на ПрАТ «Львівський локомотиворемонтний завод», спрямована на підвищення технічного стану електровоза, облаштування його новими сучасними системами управління, діагностики та сигналізації, поліпшення комфортності і умов роботи локомотивної бригади. Модернізація передбачає встановлення комплекту електрообладнання для автоматичного керування рекуперативним гальмуванням та сертифікованих систем локомотивної сигналізації АЛС-МУ та радіозв'язку типу РЛ-2С для підвищення надійності системи управління безпеки руху при управлінні електровозом.

Вчені ДНУЗТ ім. ак. Лазаряна запропонували проект модернізації електричної силової схеми електровозу $8 \mathrm{G}$ на плавне тиристорне автоматичне регулювання напруги на тягових двигунах в режимах тяги і реостатного гальмування. Модернізація дозволить збільшити масу поїзда до 10-12\%, підвищити швидкість руху до $12 \%$, покращити надійність роботи тягових двигунів, знизити питомі витрати енергії до 8\%. Таким чином, модернізація дозволяє істотно скоротити експлуатаційні витрати. На сьогоднішній день продукція вітчизняних виробників вже здатна конкурувати з імпортною продукцією.

При виконанні проектів модернізації тягового рухомого складу доцільно здійснювати моніторинг утримання локомотивної техніки експлуатантом впродовж всього життєвого циклу, встановивши контроль за коефіцієнтом технічної готовності.

Коефіцієнт технічної готовності - це відношення кількості локомотиво-днів перебування тягового рухомого складу в технічно справному стані до загальної кількості локомотиво-днів використання парку тягового рухомого складу (1):

$$
\alpha_{T \Gamma}=\frac{\pi Д_{T \Gamma}}{Л_{B}}
$$

$\alpha_{\text {тГ }}$-коефічієнт технічної готовності

ЛД

лД, -загальна кількість локомотиво-днів використання парку.

Зазвичай коефіцієнт технічної готовності тягового рухомого складу використовують для оцінки ступеня готовності парку локомотивів до перевезень протягом року, отже ЛД $=360$ днів. Коефіцієнт технічної готовності є основним

Вісник економіки транспорту і промисловості № 58, 2017 
показником ефективності роботи технічної служби експлуатанта. Цей коефіцієнт $\epsilon$ системним показником зворотного зв'язку в комплексі виконування робіт 3 технічного обслуговування i ремонту локомотивів, тому вважаємо за доцільне прийняти його у якості цільової функції (2) [14]:

$$
\sum_{i=1}^{n} \alpha_{T \Gamma} \rightarrow \max
$$

Передача частини функцій 3 технічного обслуговування та поточного ремонту спеціальним сервісним мережам, створеним за участю заводів, що виготовляють або модернізують локомотиви, дозволить значно поліпшити експлуатаційну ефективність і вирішити проблему підвищення коефіцієнта технічної готовності.

3 фінансової точки зору, залучення позикових коштів виправдано в разі високої рентабельності залізниці, коли вартість позикового капіталу менше, ніж доходність, яку він забезпечує, що дозволяє використовувати ефект фінансового важеля. Пасажирські перевезення Укрзалізниці $\epsilon$ збитковими, рентабельність вантажних перевезень компанією не розголошується, але очевидно, що УЗ вважає іiі недостатньою, оскільки наполягає на зростанні тарифів. Отже, боргове фінансування в таких умовах $\epsilon$ вкрай ризикованим.

Приватизація об'єктів інфраструктури залізничного транспорту вкрай небажана через їх стратегічну, економічну, соціальну значущість. А обмеження державного бюджету в умовах кризи не дозволяють фінансувати ефективне i повноцінне оновлення парку локомотивів. Виходячи 3 обставин, що склалися, потрібно досягнення балансу інтересів і узгоджена взаємодія між владою i бізнесом, тобто розвиток державно-приватного партнерства.

Необхідність застосування концесії та державно-приватного партнерства для модернізації тягового рухомого складу та ефективного реформування залізничної галузі обумовлюється наступними факторами, що сприяють вступу в державно приватний альянс [15].

По-перше, такі мережеві монопольні сегменти, як залізнична галузь, мають стратегічне та соціально-політичне значення, отже не мають бути приватизовані, тому їх розширене відтворення лягає додатковими витратами на державний бюджет;

По-друге, катастрофічний знос тягового рухомого складу стає джерелом можливих інфраструктурних та техногенних криз і катастроф;

По-третє, значний знос активів УЗ створює інфраструктурні обмеження та погіршує основні показники галузі (пропускну здатність залізниці), що здійснює негативний вплив на розвиток економіки, інтенсивність господарських зв'язків та призводить до зростання собівартості товарів і послуг [15].

Отже, для отримання максимального позитивного ефекту від модернізації галузі, механізми державно-приватного партнерства доцільно поширити на утримання локомотивної техніки впродовж всього життєвого циклу: від виконання проектів модернізації до передачі такого парку в оренду приватній компанії.

Висновки. Зростання тарифів на вантажні перевезення не $\epsilon$ ефективним засобом вирішення проблем УЗ. Необхідним є системний підхід до реформування галузі, перш за все, відокремлення перевезень та інфраструктури (що доречи є типовим для розвинених країн) і розробка економічно обгрунтованих планів модернізації активів. Інфраструктурою має опікуватись держава, тоді як забезпечення перевезень $\epsilon$ прерогативою УЗ. Регулювання тарифів має здійснюватись на основі глибокого вивчення тенденцій ринку, попиту та платоспроможності споживачів.

Для поповнення парку тягового рухомого складу доцільним $є$ залучення приватних власників, які можуть надати локомотиви в оренду або передати в експлуатацію залізничної компанії за

Вісник економіки транспорту і промисловості № 58, 2017 
договором концесії. Це дозволить поповнити парк локомотивів без капітальних витрат 3 боку експлуатанта. Використання механізмів державноприватного партнерства впродовж всього життєвого циклу локомотивів дозволить створити ефективну модель ринку залізничної тяги.

Наукова новизна роботи полягає в дослідженні тарифних складових залізничної тяги, структури життєвого циклу локомотиву та впливу на нього модернізації. Перспективи подальших досліджень полягають у розробці ефективної моделі формування тарифів на залізничні перевезення в Україні.

\section{ПЕРЕЛІК ВИКОРИСТАНИХ ДЖЕРЕЛ}

1. Колесникова Н.M. Теорія адаптивно-гармонізаційного механізму ціноутворення на залізничному транспорті: [монографія] / Н.М. Колесникова. - К., КУЕTТ, 2007. - 349c.

2. Бараш Ю. С. Управління залізничним транспортом країни: [монографія] / Ю. С. Бараш. - Д.: Вид-во Дніпропетр. нац. ун-ту залізн. трансп. ім. акад. В.Лазаряна, 2006. - 252 с.

$$
3 . \quad \text { Чорний }
$$

B.B. Конкурентоспроможність залізниць на ринку вантажних перевезень: теорія, методологія, практика: [монографія] / В.В. Чорний. - К.: ДЕТУТ, 2012. - 401 с.

4. Дикань В.Л. Регулювання економічної діяльності підприємств залізничної галузі / .Л. Дикань, Н.В. Чебанова // Вісник економіки транспорту і промисловості. - 2009. - №. 25. - С. 11-20.

5. Чебанова Н.В. Теоретические подходы к совершенствованию системы ценообразования на основе учета спроса на грузовые перевозки / Н.В. Чебанова, Л.Е. Ревуцкая // Коммунальное хозяйство городов: Науч.-техн. сб. Серия: экономические науки. - 2001. - Вып. 34. - С. 170-177.

6. Кірдіна О.Г. Оновлення рухомого складу залізничного транспорту: вектор на вітчизняного виробника / О.Г. Кірдіна // Вісник економіки транспорту i промисловості . - 2013. - № 41. - с. 106-109.

7. Галушко O.I. Економічні та технологічні аспекти формування оптимального парку локомотивів в умовах кризи / O.I. Галушко // Вісник економіки транспорту і промисловості. - Х.: Вид-во УкрДУЗТ, 2017. - №57. - с.82-90.

8. Башко В. Железнодорожные перевозки: тарифные недореформы поукраински // Зеркало недели: Украина, 2016. - №7: [Електронний ресурс]. - Режим доступу:

http://gazeta.zn.ua/finances/zheleznodorozhny e-perevozki-tarifnye-nedoreformy-poukrainski-_.html. - Загл. с экрана.

9. Шкляр А. Нова тарифна політика Укрзалізниці: як знайти баланс 3 національною економікою // VoxUkraine, 2015: [Електронний ресурс]. - Режим доступу:

http://archive.voxukraine.org/2015/10/19/nova -taryfna-polityka-ukrzaliznytsi-ua/ . - Назва 3 екрана.

10. Корнієнко В. Вантажні перевезення: як розв'язати тарифний вузол // Бізнес Цензор, 2017: [Електронний pecypc]. - Режим доступу: http://biz.censor.net.ua/columns/3019606/vanta jn_perevezennya_yak_rozvyazati_tarifniyi_vuz ol. - Назва з екрана.

11. Уляницький Д. Мільярди шукають в тарифі: "Укрзалізниця" має намір підвищити вартість перевезення пасажирів і вантажів // РБК-Україна, 2017: [Електронний ресурс]. - Режим доступу: https://daily.rbc.ua/ukr/show/ukrzaliznytsyanamerena-povysit-stoimost-1482767175.html. - Назва $з$ екрана.

12. Правило золотої середини: що не так з тарифами Укрзалізниці // Залізниця без корупції, 2017: [Електронний ресурс]. Режим доступу: http://zbk.org.ua/2017/03/19/pravilozoloto\%D1\%97-seredini-shho-ne-tak-ztarifami-ukrzaliznici/. - Назва з екрана.

13. Методика определения стоимости жизненного цикла, лимитной цены 
подвижного состава и сложных

технических систем железнодорожного транспорта (основные положения).- М.: OAO «РЖД», 2007. - 62c.

14. Менухова Т.А. Унификация понятий «коэффициент технической готовности», «коэффициент выпуска» и «коэффициент использования автомобилей» с учетом применения новых временных показателей / Т.А. Менухова // Транспортное дело России . - М., 2013. №1. - c.89-94.

15. Павлюченко С.H.

Государственно-частное партнерство:

боеготовность бизнеса / С.Н. Павлюченко // Вагонный парк. - Х., 2011. - №6. - с. 23-27.

\title{
УДКз36.64:629.5
}

\section{РОЗВИТОК СУДНОБУДІВНОЇ ІНДУСТРІЇ В КОНТЕКСТІ РЕФОРМУВАННЯ ТРАНСПОРТНОЇ СИСТЕМИ УКРАЇНИ}

\author{
Гришина Л.О., к.е.н., доцент, \\ Карась П.М. ., к.е.н., професор, \\ Приходько Н.В. к.е.н., доцент (НУК ім. адм.Макарова)
}

В статті визначено місце $і$ значення суднобудівної індустрії у забезпеченні функціонування транспортної системи країни. Досліджено стан суднобудівних підприємств та виявлено негативні аспекти як політичного, так і економічного впливу на створення ефективних умов діяльності галузі. Досліджено динаміку коливань обсягів виробництва, фінансових результатів та умов створення законодавчого та нормативного впровадження економічних важелів у діяльність галузі Сформульовано рекомендачії щуодо застосування інструментарію оновлення суднобудівної індустрії в аспекті забезпечення реформування і розвитку транспортної системи.

Ключові слова: транспортна система, водний транспорт, суднобудівна індустрія, підприємства суднобудування

\section{РАЗВИТИЕ СУДОСТРОИТЕЛЬНОЙ ИНДУСТРИИ В КОНТЕКСТЕ РЕФОРМИРОВАНИЯ ТРАНСПОРТНОЙ СИСТЕМЫ УКРАИНЫ}

\author{
Гришина Л.А., к.э.н., доцент, \\ Карась П.Н. ., К.э.н., професор, \\ Приходько Н.В. к.э.н., доцент (НУК им. адм.Макарова)
}

В статье определено место и значение судостроительной индустрии в обеспечении функиионирования транспортной системь странь. Исследовано состояние судострочтельных предприятий и выявлены негативные аспекты как политического, так и экономического влияния на создание эффективных условий деятельности отрасли. Исследована динамика колебаний объемов производства, финансовых результатов и условий создания законодательного и нормативного внедрения экономических рычагов в деятельность отрасли Сформулированы рекомендации по применению инструментария обновления судостроительной

(С Гришина Л.О.,

Карась П.М., Приходько Н.В.

Вісник економіки транспорту і промисловості № 58, 2017 